University of Nebraska - Lincoln

DigitalCommons@University of Nebraska - Lincoln

\title{
Simplified Method for Soil Particle-Size Determination to Accompany Soil-Quality Analyses
}

\author{
T. A. Kettler \\ University of Nebraska-Lincoln, tkettler2@unl.edu \\ John W. Doran \\ University of Nebraska-Lincoln, jdoran1@unl.edu \\ T. L.. Gilbert
}

Follow this and additional works at: https://digitalcommons.unl.edu/usdaarsfacpub

Part of the Agricultural Science Commons

Kettler, T. A.; Doran, John W.; and Gilbert, T. L.., "Simplified Method for Soil Particle-Size Determination to Accompany Soil-Quality Analyses" (2001). Publications from USDA-ARS / UNL Faculty. 305.

https://digitalcommons.unl.edu/usdaarsfacpub/305

This Article is brought to you for free and open access by the U.S. Department of Agriculture: Agricultural Research Service, Lincoln, Nebraska at DigitalCommons@University of Nebraska - Lincoln. It has been accepted for inclusion in Publications from USDA-ARS / UNL Faculty by an authorized administrator of DigitalCommons@University of Nebraska - Lincoln. 


\title{
Simplified Method for Soil Particle-Size Determination to Accompany Soil-Quality Analyses
}

\author{
T. A. Kettler,* J. W. Doran, and T. L. Gilbert
}

\begin{abstract}
Soil textural analysis is a key component of any minimum data set used for assessing soil quality and sustainability of agriculturalmanagement practices. However, conventional methods of soil textural analysis can be costly and time-consuming. The objective of this study was to develop a rapid and simple method for evaluating soil particle-size distribution, which could be employed as a tool for initial soil-quality assessment. The method uses a combination of sieving and sedimentation steps and is designed to be used in conjunction with analysis of particulate organic matter (POM), or as a stand-alone textural analysis. Soils of varied texture and organic-matter content were collected from six sites in the Great Plains. Their sand, silt, and clay contents were determined using the proposed methods and standard hydrometer and pipette techniques. Averaged across all soils, absolute differences between the proposed and standard pipette analyses were $<\mathbf{2} \%$ for sand, silt, and clay. Relative differences were $\mathbf{6}$, -1 , and $-4 \%$ for sand, silt, and clay, respectively. Coefficients of variation within soil samples averaged $<\mathbf{5} \%$ for sand, silt, and clay fractions. Regression analysis between proposed and standard pipette methods produced coefficient of determination $\left(r^{2}\right)$ values of 0.99 , 0.98 , and 0.93 for sand, silt, and clay, respectively, and 0.98 across all particle-size ranges. The method provides an inexpensive and reliable estimate of soil texture, useful in soil-quality assessment.
\end{abstract}

So OIL TEXTURE refers to the relative size distribution of the primary particles in a soil. Particle size, using the USDA classification scheme, is divided into three major size classifications: sand $(2.0-0.05 \mathrm{~mm})$, silt $(0.05-$ $0.002 \mathrm{~mm}$ ), and clay $(<0.002 \mathrm{~mm})$ (Gee and Bauder, 1986). Soil textural composition (\% sand, silt, and clay) affects soil-water retention chracteristics, leaching and erosion potential, plant nutrient storage, organic-matter dynamics, and carbon-sequestration capability. Soil textural analysis is a key component of any minimum data set to be used for assessing soil quality and sustainability of agricultural management practices. However, conventional methods of soil textural analysis are costly (\$7-\$18 per sample) and time-consuming, requiring specialized equipment (e.g., hydrometer, sedimentation cylinders, pipettes), time, and resources to process samples by commercial or research laboratories. Further, the technology is not immediately accessible to agricultural consultants, conservationists, and specialists working with producers.

USDA-ARS, 119 Keim Hall, Lincoln, NE 68583-0934. Journal Series no. 13277 of the Agric. Res. Div., Univ. of Nebraska, Lincoln, NE. Received 28 May 1999. *Corresponding author (tkettler@unlserve. unl.edu).

Published in Soil Sci. Soc. Am. J. 65:849-852 (2001).
Soil textural analysis is accomplished by first dispersing the soil into individual primary particles, followed by fractionation and quantification of each particle-size interval by sieving or sedimentation. The hydrometer and pipette methods are sedimentation procedures that are accepted as standard methods of particle-size analysis (Gee and Bauder, 1986). Soil dispersion can be accomplished using a combination of chemical and mechanical means. Chemical dispersion in standard pipette and hydrometer procedures uses hydrogen peroxide $\left(\mathrm{H}_{2} \mathrm{O}_{2}\right)$ and sodium hexametaphosphate [HMP, $\left.\left(\mathrm{NaPO}_{3}\right)_{\mathrm{n}}\right]$, also known as sodium metaphosphate. Hydrogen peroxide oxidizes organic matter, which binds soil particles into aggregates. The function of HMP is to complex any $\mathrm{Ca}^{2+}$ in solution and to replace $\mathrm{Ca}^{2+}$ with $\mathrm{Na}^{+}$on the ion-exchange complex of soil particles, resulting in the dispersion of individual soil particles and causing breakdown of soil aggregates. Mechanical agitation used in conjunction with chemical treatments enhances the dispersion. After dispersal, sieving and/or sedimentation procedures are used to fractionate the soil particles of each size class. For particle diameters $<0.05 \mathrm{~mm}$, sieving is inefficient and difficult, and sedimentation in water is the preferred procedure. In sedimentation, a suspension of the dispersed sample is allowed to settle, and measurements are made of the solution density at a specific depth within the sedimentation cylinder. Stokes' Law relates the time of settling to the size of particles remaining suspended in solution (Gee and Bauder, 1986).

The objective of this study was to develop a rapid and simple method for evaluating soil particle-size distribution, which could be employed as a tool for initial soil-quality assessment. The method was designed to be used in conjunction with an analysis of particulate organic matter (POM) as part of a battery of standard soil-quality analyses developed by researchers (Cambardella and Elliott, 1992; Doran and Jones, 1996; Cambardella et al., 2001) or as a stand-alone textural analysis.

\section{MATERIALS AND METHODS}

\section{Particulate Organic Matter Method}

In the POM by loss on ignition (LOI) procedure of Cambardella et al. (2001), soil-particle dispersion is accomplished by adding HMP, at an aqueous concentration of $0.5 \%$ by weight,

Abbreviations: HMP, hexametaphosphate; LOI, loss on ignition; POM, particulate organic matter. 
and shaking the soil sample ( $<2 \mathrm{~mm}$ ) for $16 \mathrm{~h}$ (overnight) on a reciprocating shaker at 120 reciprications per minute in a container with a 3:1 HMP $(90 \mathrm{~mL})$ to soil $(30 \mathrm{~g})$ ratio. After dispersion, the soil slurry is sieved through nested standard 0.5-mm mesh (no. 35) and 0.053-mm mesh (no. 270) sieves to separate sand particles and POM. The collected sand particles $(>0.053 \mathrm{~mm})$ are dried at $55^{\circ} \mathrm{C}$ to constant weight, then subjected to $450^{\circ} \mathrm{C}$ for $4 \mathrm{~h}$ to measure POM by LOI. The sand percentage is based on its fraction of the original sample mass and can be calculated using the mass of sand after either $55^{\circ} \mathrm{C}$ or $450^{\circ} \mathrm{C}$. The mass after heating to $450^{\circ} \mathrm{C}$ will have greater accuracy, since any organic matter will have been oxidized at the higher temperature.

During sand-particle and POM separation, the solution and particles (silt + clay) passing the sieve are collected in a bucket and then transferred to a 1-L beaker. This solution is stirred thoroughly to achieve suspension of all soil particles. While stirring, a 45-mL subsample is collected from the suspension using a $60-\mathrm{mL}$ syringe and transferred to a $50-\mathrm{mL}$ centrifuge tube. The subsample is shaken vigorously (capped tightly) and then left undisturbed at room temperature $\left(18-24^{\circ} \mathrm{C}\right)$ with a vertical orientation for at least $90 \mathrm{~min}$ but $<6 \mathrm{~h}$ to allow silt particles to settle. After the sedimentation period, the solution containing the suspended clay is decanted into a pre-weighed drying pan. The settled silt particles are then rinsed into another pre-weighed drying pan, and both are dried at $105^{\circ} \mathrm{C}$ to constant weight.

The relative proportion of silt in the dried subsample is calculated as:

Total subsample mass $=$

$$
\begin{aligned}
& \text { (oven dry silt mass }+ \text { oven dry clay mass) } \\
& \text { Subsample silt }=\frac{\text { oven dry silt mass }}{\text { total subsample mass }}
\end{aligned}
$$

This is then used to calculate the percentages of silt and clay in the original sample:

$$
\begin{aligned}
\text { Sand } \% & =\left(\frac{\text { oven dry sand mass }}{\text { original sample mass }}\right) \times 100 \% \\
(\text { Silt }+ \text { Clay } \% & =100-\text { Sand } \% \\
\text { Silt } \% & =\text { Subsample silt } \times(\text { Silt }+ \text { Clay }) \% \\
\text { Clay } \% & =100-(\text { Sand } \%+\text { Silt } \%)
\end{aligned}
$$

\section{Rapid Method}

When using the method as a stand-alone procedure (no POM analysis), several steps can be eliminated to simplify the procedure. The concentration of aqueous HMP is increased to $3 \%$, and shaking time reduced to $2 \mathrm{~h}$. There is no collection of sand and POM of the 2.0- to $0.5-\mathrm{mm}$ range, so only a $0.053-\mathrm{mm}$ sieve is necessary to collect the sand fraction. A smaller original soil mass $(15 \mathrm{~g})$ can be used for the analysis, reducing the volume of liquid required to rinse the silt and clay particles through the sieve. This smaller volume of solution can be collected in a $600-$ or $800-\mathrm{mL}$ beaker, and the sedimentation step carried out without subsampling. The silt and clay solution is stirred thoroughly to suspend all particles, then allowed to settle undisturbed at room temperature $\left(18-24^{\circ} \mathrm{C}\right)$ for a sedimentation period of at least $90 \mathrm{~min}$ but $<6 \mathrm{~h}$. After the sedimentation period, the suspended clay fraction is decanted from the settled silt particles and discarded. The settled silt fraction is then dried in the beaker at $105^{\circ} \mathrm{C}$ to constant weight. The soil Sand \% and Silt\% are calculated based on their fraction of the original sample mass:

$$
\begin{aligned}
\text { Sand } \% & =\left(\frac{\text { oven dry sand mass }}{\text { original sample mass }}\right) \times 100 \% \\
\text { Silt } \% & =\left(\frac{\text { oven dry silt mass }}{\text { original sample mass }}\right) \times 100 \%
\end{aligned}
$$

The clay $\%$ is determined by calculating the difference of $100 \%$ minus the sum of the Sand \% and Silt \%,

$$
\text { Clay } \%=100-(\text { Sand } \%+\text { Silt } \%)
$$

\section{Method Evaluation}

In the development stages of the POM and rapid methods, the parameters of HMP concentration, shaking time, sedimentation time, and the ratio of dispersant volume to soil mass were all considered and tested for impact upon the accuracy of results (data not shown). After preliminary investigations with varying configurations of these parameters, the procedures summarized earlier were deemed the best fit to the goals of accuracy, simplicity, and expediency.

To evaluate the methods, soils of various textural composition and organic matter contents were collected from six agricultural field research sites in the U.S. central Great Plains region (Table 1). At four of the sites, five separate samples were collected from the 7.5- to $30-\mathrm{cm}$ depth of different research plots and each one analyzed separately. At the Valen-

\begin{tabular}{|c|c|c|c|c|c|}
\hline Sample site & $\begin{array}{c}\text { Soil series/ } \\
\text { surface texture }\end{array}$ & Classification & Management & Depth & $\begin{array}{l}\text { Organic } \\
\text { matter } \dagger\end{array}$ \\
\hline & & & & cm & $\%$ \\
\hline Akron, CO & Weld silt loam & Fine, smectitic, mesic Aridic Argiustolls & tilled cropland & 7.5-30 & 1.22 \\
\hline Brown Co., NE & Valentine sand & Typic mixed, mesic Ustipsament & grassland & 0-20 & 0.73 \\
\hline Cass Co., NE & $\begin{array}{l}\text { Sharpsburg (1) } \\
\text { silty clay loam }\end{array}$ & Fine, smectitic, mesic Typic Argiudolls & tilled cropland & 0-20 & 2.98 \\
\hline Mandan, ND & $\begin{array}{l}\text { Temvik-Wilton } \\
\text { silt loam }\end{array}$ & Fine loamy, mixed, Typic Argiboroll & tilled cropland & 7.5-30 & 2.34 \\
\hline Mead, NE & $\begin{array}{l}\text { Sharpsburg (2) } \\
\text { silty clay loam }\end{array}$ & Fine, smectitic, mesic Typic Argiudolls & tilled cropland & 7.5-30 & 2.56 \\
\hline Sidney, NE & Duroc loam & $\begin{array}{l}\text { Fine-silty, mixed, superactive, mesic } \\
\text { Pachic Haplustolls }\end{array}$ & no-till cropland & 7.5-30 & 1.79 \\
\hline
\end{tabular}
tine and Sharpsburg-1 (Cass County, Nebraska) sites, one sample was collected from the $0-$ to $20-\mathrm{cm}$ depth. The samples were air-dried, and sieved to $<2.0 \mathrm{~mm}$ before analysis. Three trials each of the POM and Rapid method were run on the 22 different soil samples collected from the six field locations. Precision of the methods was evaluated using the coefficient of variation $(\mathrm{CV})$ calculated from the three trials of each

Table 1. Location, series, classification, management, and percentage organic matter for six soils collected from the U.S. Great Plains. 
method done on each soil sample, and an average CV calculated from the 22 different soil samples to estimate the precision of the methods across all samples. The accuracy of the experimental results was evaluated by comparison with the analysis of these same soils by the USDA-NRCS National Soil Survey Laboratory in Lincoln, NE, using the pipette method (Gee and Bauder, 1986). In addition, each sample was analyzed by an independent commercial soil testing laboratory in Lincoln, NE, and the University of Nebraska (UNL) soil and plant analysis laboratory using standard hydrometer techniques (Gee and Bauder, 1986). The commercial, UNL, and NRCS labs performed one analysis per sample on each of the 22 soil samples. Results of the POM and Rapid methods, and those of the commercial labs using the hydrometer method, were compared with results of the pipette analysis done by the NRCS lab. Absolute and relative differences for each sample were calculated using the NRCS pipette analysis as the standard of comparison. Simple linear regressions (with the $y$-intercept term forced to 0 ) were done, and coefficients of determination $\left(r^{2}\right)$ calculated to compare results of the POM, Rapid, and hydrometer methods to those of the pipette method. Results from the two commercial labs using the hydrometer method were combined for comparison purposes.

\section{RESULTS AND DISCUSSION}

Precision of the POM and Rapid methods, measured by the $\mathrm{CV}$ within soil samples, ranged from 0 to $6 \%$, and across all samples averaged $2 \%$ for the sand and silt, and $3 \%$ for clay fractions (data not shown). Absolute differences for sand content (Table 2) between pipette and the POM and Rapid methods ranged from -1.4 to $3 \%$, with a mean difference across sites of $1.4 \%$. The relative difference of the means between methods across sites was $6 \%$. Plots of the sample site means for sand, silt, and clay, of the POM, Rapid, and hydrometer methods against the pipette method are shown in Fig. 1. Regression of the results of the POM and Rapid methods against the pipette for sand content showed that the proposed methods produced similar results $(y=1.02 x$, $\left.r^{2}=0.99\right)$, and had greater coefficients of determination $\left(r^{2}\right)$ than those of the hydrometer method $\left(r^{2}=0.94\right)$. Absolute differences for silt content (Table 2) between the pipette and the POM methods ranged from -2 to $2 \%$, with a mean difference of $<1 \%$, and a mean relative difference of $<2 \%$. Regression of silt contents from the POM method against the pipette showed a good correlation between the two methods $\left(y=0.99 x ; r^{2}=\right.$ 0.98 ). The Rapid method produced mean absolute and relative differences in silt content of $<1 \%$. Regression of the Rapid method against the pipette also illustrated the good comparison of methods ( $y=0.999 x ; r^{2}=0.99$ ). Clay content (Table 2) by both the POM and Rapid methods had mean absolute and relative differences of $-1 \%$ and $4 \%$, respectively. Regression of the POM method against pipette analysis for clay content showed good correlation between the two methods $(y=0.95 x$; $\left.r^{2}=0.93\right)$, while the Rapid method showed slightly greater accuracy compared with the pipette method $(y=$ $\left.0.96 x ; r^{2}=0.97\right)$. Over all particle size ranges, the regression of methods against the pipette method was $y=$ $0.99 x, r^{2}=0.98$ for the POM method; $y=0.99 x, r^{2}=$ 0.99 for the Rapid method; and $y=0.96 x, r^{2}=0.92$ for the hydrometer method.

The POM and Rapid methods were designed to provide basic information to accompany other soil-quality indicators as part of a minimum data set for screening soil quality and health. For simplicity and expediency of analysis, some factors that may affect the accuracy of results are consciously neglected. Destruction of soil organic matter, a step included in the standard hydrometer and pipette methods, has been omitted here.

The POM and Rapid methods provide means to evaluate soil texture rapidly and with sufficient accuracy for soil-quality screening purposes. They should be useful to agricultural consultants, conservationists, and specialists

Table 2. Soil sand, silt, and clay percentages of six soils by proposed particulate organic matter (POM) and Rapid methods, and by standard pipette and hydrometer techniques.

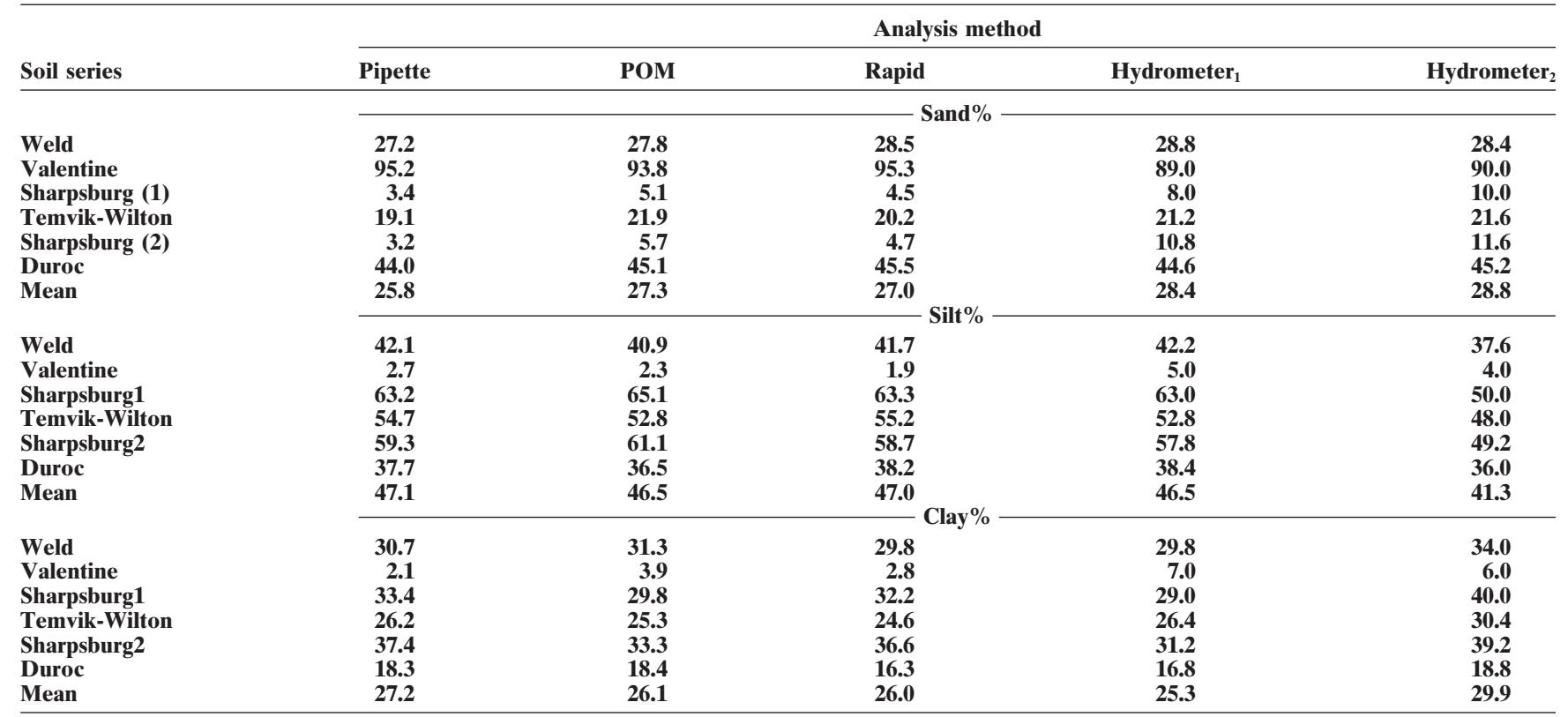


1a. POM Method vs Pipette

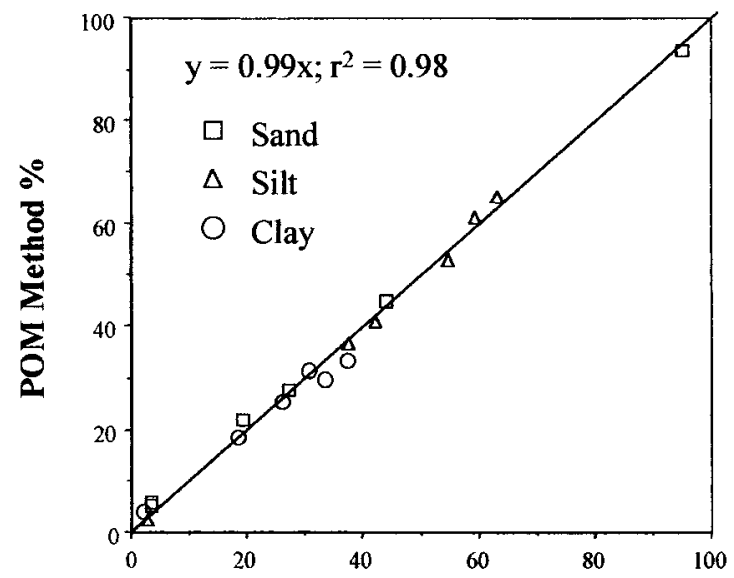

1b. Rapid Method vs. Pipette

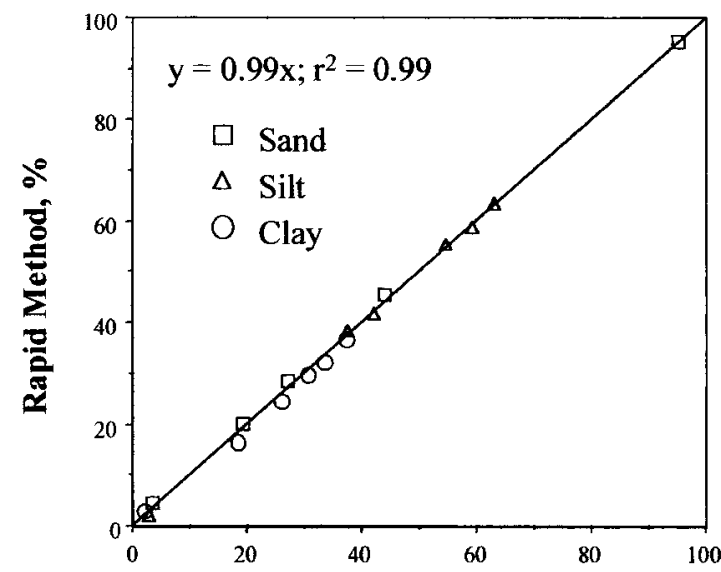

1c. Hydrometer vs. Pipette

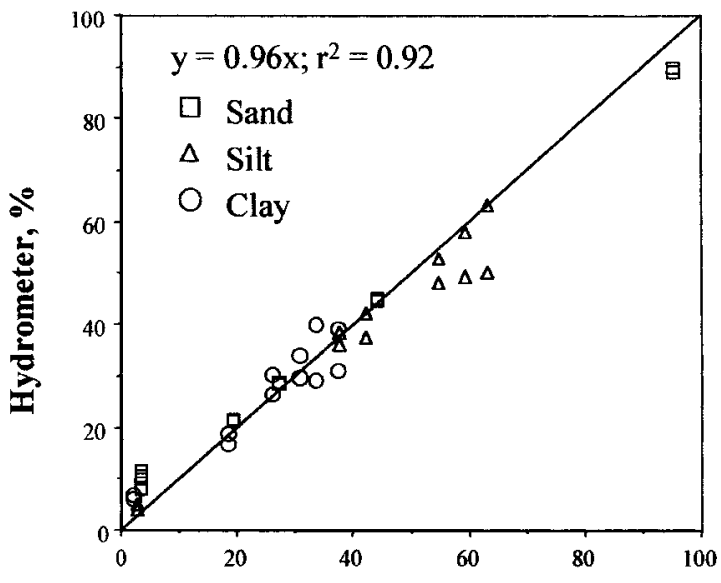

Pipette Method, \%

Fig. 1. Comparison of (a) particulate organic matter (POM), (b) Rapid, and (c) hydrometer methods with standard pipette method for determination of soil sand, silt, and clay fractions. Each point plotted represents the mean of all samples taken at each location. The linear plot of $y=x$ is shown to illustrate deviation of methods from pipette standard. working with producers, providing simple soil texture estimates necessary in soil quality and management sustainability assessments. A large number of samples can be processed in a relatively short time with minimal equipment and expertise. Equipment necessary for the analyses are (i) a balance accurate to $0.1 \mathrm{~g}$; (ii) a standard 0.053-mm mesh (No. 270) sieve; (iii) an oven for sample drying; and (iv) miscellaneous glassware for sample stirring, shaking, etc. The balance and sieve are items obtainable from scientific supply catalogs at minimal cost. The syringe, centrifuge tubes, and weighing pans, used with the POM analysis, are common items available in a laboratory, but in themselves are not integral to the analysis. Alternative equipment that suits the purpose can be improvised from items found in the kitchen or at a hardware store. On a small scale, using the Rapid method, analysis can be done in only a few short periods per day. On a larger scale, up to 60 samples can be handled easily by one person working intermittently over a couple days. Total analysis time per sample is 15 min or less, which should translate to a cost of $<\$ 5$ per sample. This is much lower than the current cost at commercial and university laboratories, which range from $\$ 7$ to $\$ 18$ per sample for labs in Lincoln, NE.

\section{REFERENCES}

Cambardella, C.A., A.M. Gajda, J.W. Doran, B.J. Wienhold, and T.A. Kettler. 2001. Estimation of particulate and total organic matter by weight loss-on-ignition. P. 349-359. In R. Lal, J.M. Kimble, R.F. Follett, and B.A. Stewart (ed.). Assessment methods for soil carbon. CRC Press, Boca Raton, FL.

Cambardella, C.A., and E.T. Elliott. 1992. Particulate soil organicmatter changes across a grassland cultivation sequence. Soil Sci. Soc. Am. J. 56:777-783.

Doran, J.W., and A.J. Jones. 1996. Methods for assessing soil quality. SSSA Spec. Publ. 49. SSSA, Madison, WI.

Gee, G.W., and J.W. Bauder. 1986. Particle-size analysis. p. 383-411. In A. Klute (ed.) Methods of soil analysis. Part 1. 2nd ed. Agron. Monogr. 9. ASA and SSSA, Madison, WI. 